УДК 656.07

ДОЦЕНКО С. І., д-р техн. наук, доцент, МОЙСЕСНКО В. І., д-р техн. наук, професор,

КЛИМЕНКО Л. А., канд. техн. наук, доцент, СРМОЛЕНКО Л. П., аспірант кафедри спеціалізованих комп'ютерних систем (Український державний університет залізничного транспорту)

\title{
Обгрунтування методології формування моделей діяльності підприємства
}

Сучасний стан розвитку виробництва характеризується зміною конщепції побудови та діяльності підприємства, тому насамперед виникає проблема прийняття рішення про обрання оптимальної методології моделювання. Після изього здійснюється вибір оптимального методу та моделі. Після обрання оптимальної моделі наступною є фаза ї̈ конструювання. При иьому процес конструювання містить етапи декомпозиції, агрегування, дослідження умов, побудови програми. Зміст иього підходу до моделювання $\epsilon$ конкретним втіленням загальної методології структурно-функціонального підходу до дослідження організаційних систем. На ией час немає єдино визнаної методології моделювання підприємства, тому розробники використовують переважно евристичні методи для прийняття рішень.

Ключові слова: методологія, моделювання, система, організоване иіле, иілісний підхід, організаиія.

\begin{abstract}
Вступ
Дослідження методології моделювання інформаційно-керуючих систем на залізничному транспорті було започатковано у роботі [1]. Авторами визначено зміст основних понять методологій системного та цілісного підходів до представлення діяльності залізничного підприємства. Показано, що саме методологія цілісного підходу, у якій діяльність подана у формі структури задач, які вирішуються частинами організованого цілого, забезпечує вирішення основних проблем теорії діяльності, а отже, $\epsilon$ основною методологією, яку слід застосовувати при моделюванні підприємства. Методологія системного підходу $\epsilon$ допоміжною до методології цілісного підходу і забезпечує формування конкретних моделей систем 3 урахуванням визначених в ISO 14258-98 аспектів моделювання для систем, які входять до складу моделі підприємства як організованого цілого.

Проблема встановлення співвідношення для понять «система» та «організоване ціле» вирішена шляхом встановлення співвідношення між результатами діяльності організованого цілого та системи, діяльність якої присвячена вирішенню певної задачі.

Вирішення цієї проблеми полягає у необхідності дослідження конкретних методологій формування моделей діяльності підприємства, тому вона $\epsilon$ актуальною і потребує наукового аналізу.
\end{abstract}

\begin{abstract}
Аналіз досліджень
На цей час визначальною серед методологій пізнання дійсності в усіх іiі проявах $є$ методологія системного підходу, основою якої є процесний підхід. $\mathrm{y}$ системній методології розглядаються процеси, підпорядковані плину часу. Час для цих процесів $\epsilon$ аргументом функції.

Важливим питанням у теорії систем є питання побудови моделі системи. О.О. Воронін визначає зміст категорії «модель» системи, наголошуючи на тому, що поряд із загальними неоперативними визначеннями системи - моделі, що дають уявлення про неї як про «комплекс взаємопов'язаних елементів...», існує ряд у певному сенсі конструктивних визначень. Саме вони фіксують увагу на низці ऑii типових ознак i властивостей, що виявляються шляхом емпіричного узагальнення [2, с. 21].
\end{abstract}

До цих визначень О. О. Воронін відносить ознаки, що характеризують:

- внутрішню будову системи;

- iї функціонування;

- управління;

- поведінку;

- розвиток тощо.

Такі визначення мають вигляд кортежів, склад яких поступово поповнюється і варіюється залежно від цілей і особистості дослідника. Наприклад, визначення організаційної системи (ОС) як сукупності їі:

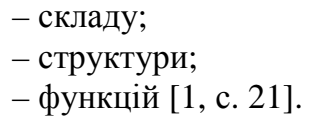

- складу;

- функцій [1, с. 21].

() С. І. Доценко, В. І. Мойсеєнко, Л. А. Клименко, Л. П. Єрмоленко, 2021 
Для побудови базової моделі системи пропонується будувати «базову» метамодель системи. Відповідно до цього підходу можна побудувати «базову» метамодель будь-якої системи у вигляді відкритого кортежу іiі «базових» ознак і властивостей, упорядкованих відповідно до емпірично обгрунтованого наростання системної (модельної) складності.

Базова модель системи [1, с. 22]:

- елементи: $\{\ldots\}$;

- структура: $\{\ldots\}$;

- функції: $\{\ldots\}$;

- динамічні властивості: $\{\ldots\}$;

- взаємодія із зовнішнім середовищем: $\{\ldots\}$;

- управління: $\{\ldots\}$;

- цілепокладання: $\{\ldots\}$;

- самоврядування: $\{\ldots\}$;

- поведінка: $\{\ldots\}$;

- гомеостазис: $\{\ldots\}$;

- самоорганізація: $\{\ldots\}$;

- розвиток: $\{\ldots\}$;

- еволюція: $\{\ldots\}$;

- $\quad$ мета дослідження: $\{\ldots\}$;

- дослідник: $\{\ldots\}$.

У дужках три крапки вказують на те, що кожний 3 елементів моделі системи може бути визначений як кортеж. Цей кортеж відкритий для доповнення та фрактального поглиблення кожної позиції залежно від об'єкта, суб'єкта і мети дослідження.

Фундаментальна системна його складових потенційно має таку саму структуру опису, тобто такі, наприклад, позиції, як «структура функцій», «функція структури», «структура структури (надструктура)», «структура функцій структури» тощо, знаходять у ньому своє місце і зміст $[1$, с. 23].

3 наведеного визначення базової моделі системи як кортежу випливає множинність (неоднозначність) визначення кожного з їі структурних елементів. Отже, кортеж має формуватися для кожного конкретного підприємства.

О. М. Новіковим методи моделювання систем поділено на якісні та кількісні. Серед якісних методів виділено [3, с. 280-284]:

- метод «сценаріїв»;

- графічні методи;

- метод структуризації;

- метод «дерева цілей»;

- морфологічний підхід;

- ділові ігри.

До колективних методів відносять також [3, c. $280-284]$ :

- «метод мозкового штурму»;

- метод «Делфі»;
- метод синектики.

3 переліку існуючих методів моделювання бачимо відсутність єдиного методу моделювання. Тому насамперед виникає проблема прийняття рішення про обрання оптимального методу моделювання.

Після цього необхідно здійснити вибір оптимальної моделі. Після обрання оптимальної моделі наступною $є$ фаза іiі конструювання. При цьому процес конструювання містить етапи декомпозиції, агрегування, дослідження умов, побудови програми [2, c. 307$]$.

Декомпозиція у свою чергу розглядається як процес поділу загальної мети проєктованої системи на окремі підцілі - завдання відповідно до обраної моделі. Декомпозиція дає змогу розчленувати всю роботу з реалізації моделі на пакет детальних робіт, що робить можливим вирішення питань їх раціональної організації, моніторингу, контролю і т. д. [2, с. 308].

Процес, у певному сенсі протилежний декомпозиції, - це агрегування (дослівно - з'єднання частин у ціле). Основними методами агрегування, якщо не брати до розгляду формальних математичних моделей, є визначення конфігуратора і використання класифікацій.

Конфігуратором називається мінімально достатній набір різних мов опису процесу вирішення проблеми. Тільки спільний (агрегований) опис у поняттях декількох мов, що якісно розрізняються, дає змогу охарактеризувати явище з достатньою повнотою.

Це міркування приводить до поняття агрегату, що складається 3 якісно різних мов опису проєктованої системи і має ту властивість, що кількість цих мов мінімальна, але необхідна для заданої мети. Цей агрегат і $є$ конфігуратором [2, с. 309-311]

Досвід проєктування організаційних систем показує, що для синтезу організаційної системи конфігуратор складається:

-3 опису розподілу влади (системи підпорядкування);

- розподілу

відповідальності

(структури функціонування);

- розподілу інформації (організація зв'язку і пам'яті системи, накопичення досвіду, навчання, історіï).

Усі три структури не мають збігатися топологічно, хоча пов'язують одні й ті самі частини системи [2].

Тобто конфігуратор для синтезу організаційної системи за даним визначенням складається 3 трьох векторів, які зображено на рис. 1.

Розглянута методологія моделювання $\epsilon$ конкретним втіленням загальної методології структурно-функціонального підходу до дослідження організаційних систем, наприклад, підприємство розглядається як складна виробнича система. 


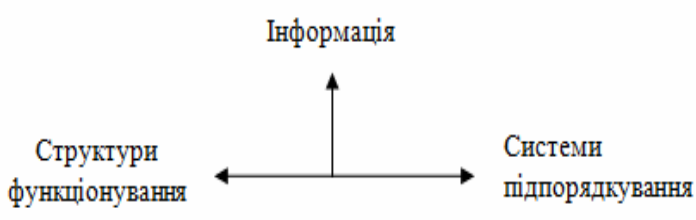

Рис. 1. Конфігуратор для синтезу організаційної системи підприємства

Аналогічний підхід розглядається В. Н. Волковою [4, с. 98]: «Мета підходу - відтворення моделей структури, елементами яких виступають функції (певним чином виділені частини діяльності)».

Ставиться завдання розроблення спеціального механізму відтворення будь-якої мислимої функції. Для цього застосовується ідея породжувальних механізмів. Як зазначається в [4, с. 98]: «Маючи достатній набір функцій, можна застосувати певні системні організаційні принципи, для того щоб задати організаційні рамки виділеним комплексам функцій і тим самим перейти до формування організаційної структури складної виробничої системи...

Інструментом аналізу діяльності в складній виробничій системі $є$ її декомпозиція, можливість якої випливає 3 системного постулату: не всі відношення явищ та об'єктів однаково сильні... Для побудови механізму відтворення функцій необхідно виявити відношення виробничої системи 3 середовищем та роди діяльності, які забезпечують існування таких відносин».

3 наведеного випливає, що організовуються комплекси функцій. 3 цих комплексів формують організаційну структуру. Первинними визнаються саме функції, які потім формуються у відповідну організаційну структуру.

Виникає питання про склад та зміст механізму відтворення функцій. Це унікальний для кожної виробничої системи механізм, чи це - механізм універсальний для будь-якої системи?

У $[4$, c. 98] запропоновано застосовувати такі роди діяльності:

- h - основну виробничу, цілеспрямовану;

- v - забезпечення життєдіяльності;

- $\mathrm{p}$ - організацію;

- с - управління;

- $\mathrm{f}$ - відновлення.

Виникає питання: як пов'язані між собою вказані роди діяльності? Насамперед це стосується родів діяльності: організаційної та управлінської. 3 наведеного випливає, що це різні роди діяльності, які не пов'язані між собою.

На основі прийнятого представлення частин діяльності зміст категорії «функція» визначається так [4, с. 101]: «Таким чином, ми об'єднуємо дві системні концепції: концепцію діяльності, яка управляється, оновлюється, організовується та стабілізується, і системотехнічну концепцію потоку, причому термін «потік» застосовується до тих ресурсів, які йдуть на відтворення функцій, а не поліструктури. Діяльність при цьому специфікована за ознаками призначення, спрямованості та логічної послідовності процесів. Фрагмент діяльності, який споряджено деякими чи всіма вказаними ознаками, називається функцією».

При цьому функція як фрагмент діяльності має такі ознаки:

- специфікована за ознаками призначення;

- цілеспрямована;

- визначена логічна послідовність процесів.

Будь-яка функція як «атомарна діяльність» має бути:

- оснащена зразком свого результату;

- предметом перетворення;

- методами та процедурами перетворення предмета в результат;

- допоміжними матеріалами та енергією, що споживаються в процесі перетворення;

- матеріальною структурою, що включає суб'єкт діяльності та знаряддя діяльності;

- вимірювальним апаратом, що оцінює результат діяльності.

Тоді вона може бути актуалізованою [4].

У цій тезі В. Н. Волкова вводить категорію «одиниця діяльності (процесу)» у формі відповідної функції, реалізація якої забезпечує отримання конкретного результату. Але визначити таким чином «одиницю діяльності (процесу)» неможливо, тому що кожному конкретному результату буде зіставлена своя функція! Одиницю для функції можна встановити тоді, коли для неї буде отриманий завжди один і той самий результат.

3 іншого боку, відомо, що для опису виробничої діяльності застосовують поняття «фактор». У розглянутих підходах, за винятком роботи [4], це поняття не розглядається. Водночас у теорії фірми це поняття широко використовується.

\section{Мета і завдання дослідження}

Метою цього дослідження $\epsilon$ обгрунтування обрання методології моделювання підприємства як системи на основі декомпозиції факторів виробничої діяльності 3 урахуванням можливостей інтелектуальних інформаційних технологій i специфіки діяльності залізниці.

\section{Аналіз методологій моделювання підприсмства як системи на основі декомпозиції факторів виробничої діяльності}

Прикладом застосування системної методології $\epsilon$ метод аналізу систем на основі декомпозиції факторів виробничої діяльності, який запропоновано В. Н. Волковою [4, с. 148]. Вона підкреслює, що ця 
схема декомпозиції $\epsilon$ загальною для будь-якої діяльності (рис. 2) [4, с. 149, рис. 10.1].

У моделі В.Н. Волкової час і простір $\epsilon$ самостійними факторами. При цьому фактори організаційної діяльності (функції, процеси) ставляться у відповідність фактору часу шляхом встановлення функціональної залежності. Водночас ресурси $є$ незалежними від часу. Вони функціонально залежать від простору та функцій діяльності. Час у цій декомпозиції діяльності розглядається як незалежний аргумент функціональної залежності.

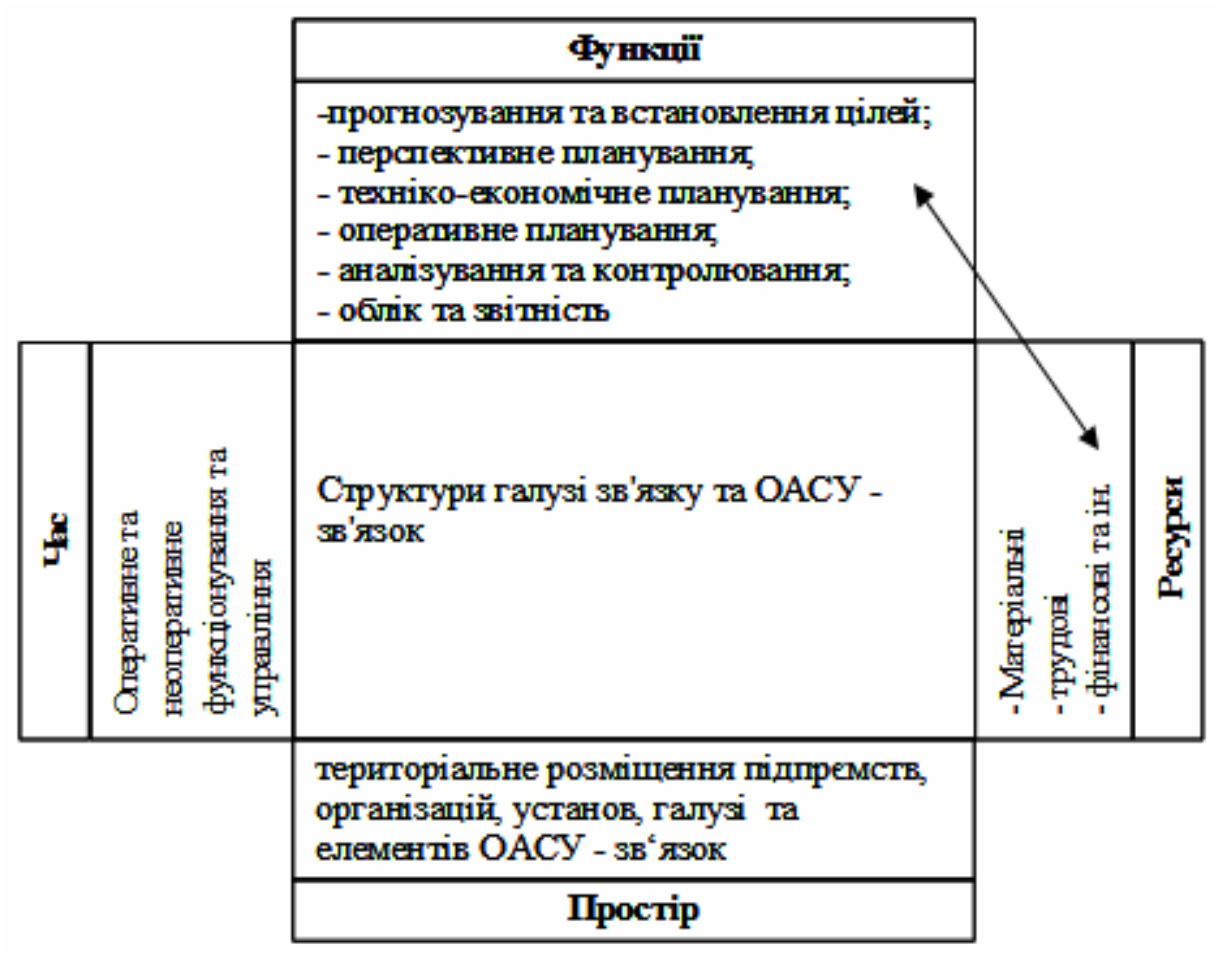

Рис. 2. Декомпозиція факторів існування та діяльності підприємства

На рис. 3 наведено площину факторів існування та діяльності організації згідно 3 [4], яку ми будемо використовувати як базову для порівняння.

Графічна ілюстрація символічного зображення систем чотирьох типів в умовних координатах «простір - час», які запропоновано Г. Клейнером у теорії фірми, наведена на рис. 4 [5].

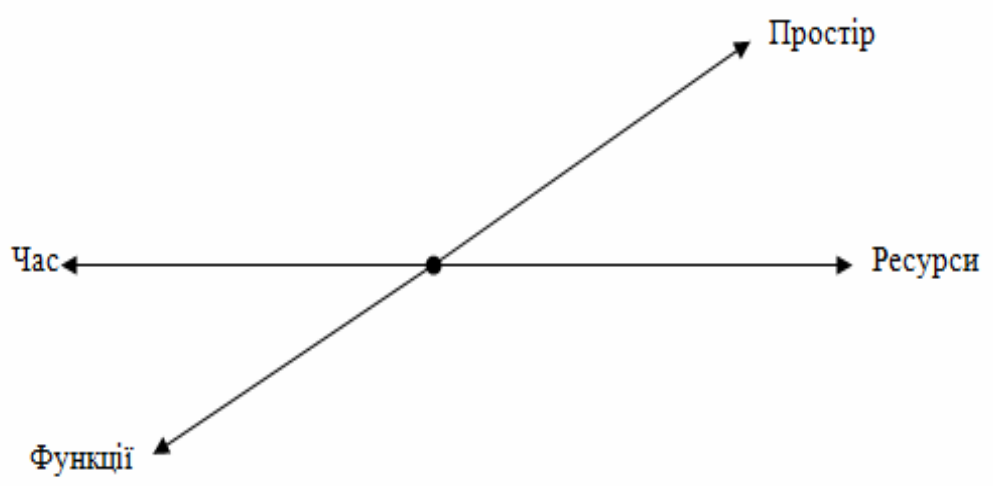

Рис. 3. Модель декомпозиції факторів існування та діяльності підприємства 


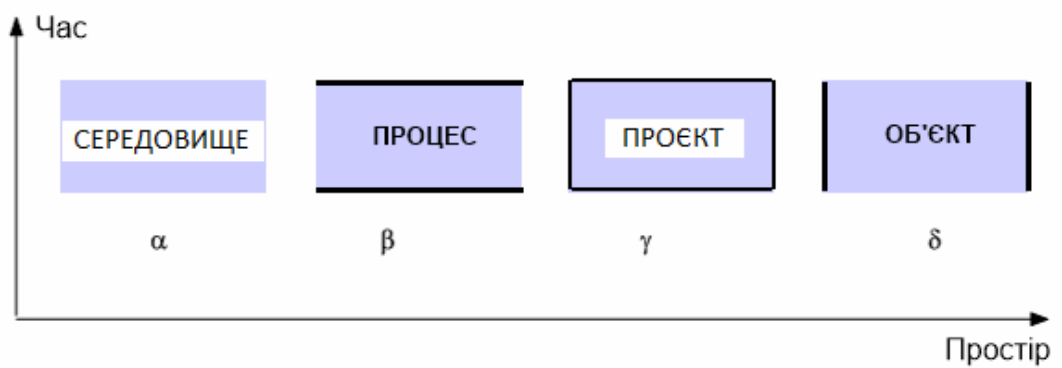

Рис. 4. Символічні зображення систем чотирьох типів в умовних координатах

Г. Клейнер запропонував класифікацію систем підприємства в просторово-часовому вимірі. Час у цій концепції характеризується тільки тривалістю реалізації процесу або проєкту [5]. Таким чином, модель Г. Клейнера належить до часових систем за М. Й. Месаровичем. На рис. 5 наведено модель декомпозиції факторів існування та діяльності підприємства (рис. 4) і для прикладу додатково наведено системи чотирьох типів діяльності підприємства за моделлю діяльності [5].

У наступній моделі, яка запропонована Д. А. Новіковим, діяльність визначається як цілеспрямована активність людини. Основні структурні (процесуальні) компоненти будь-якої людської діяльності ілюструє рис. 6.

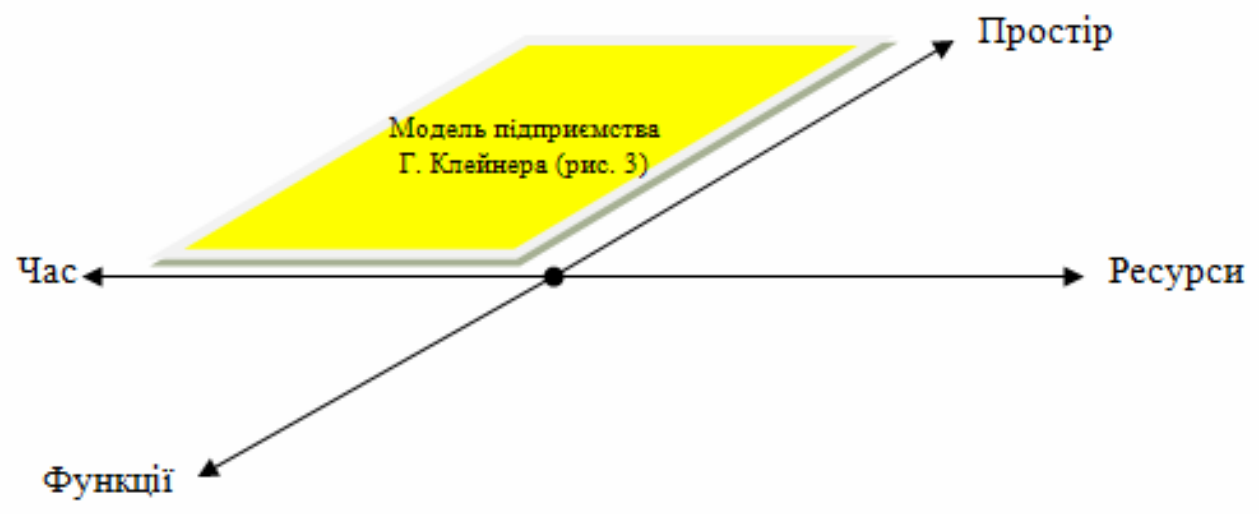

Рис. 5. Модель підприємства за Г. Клейнером

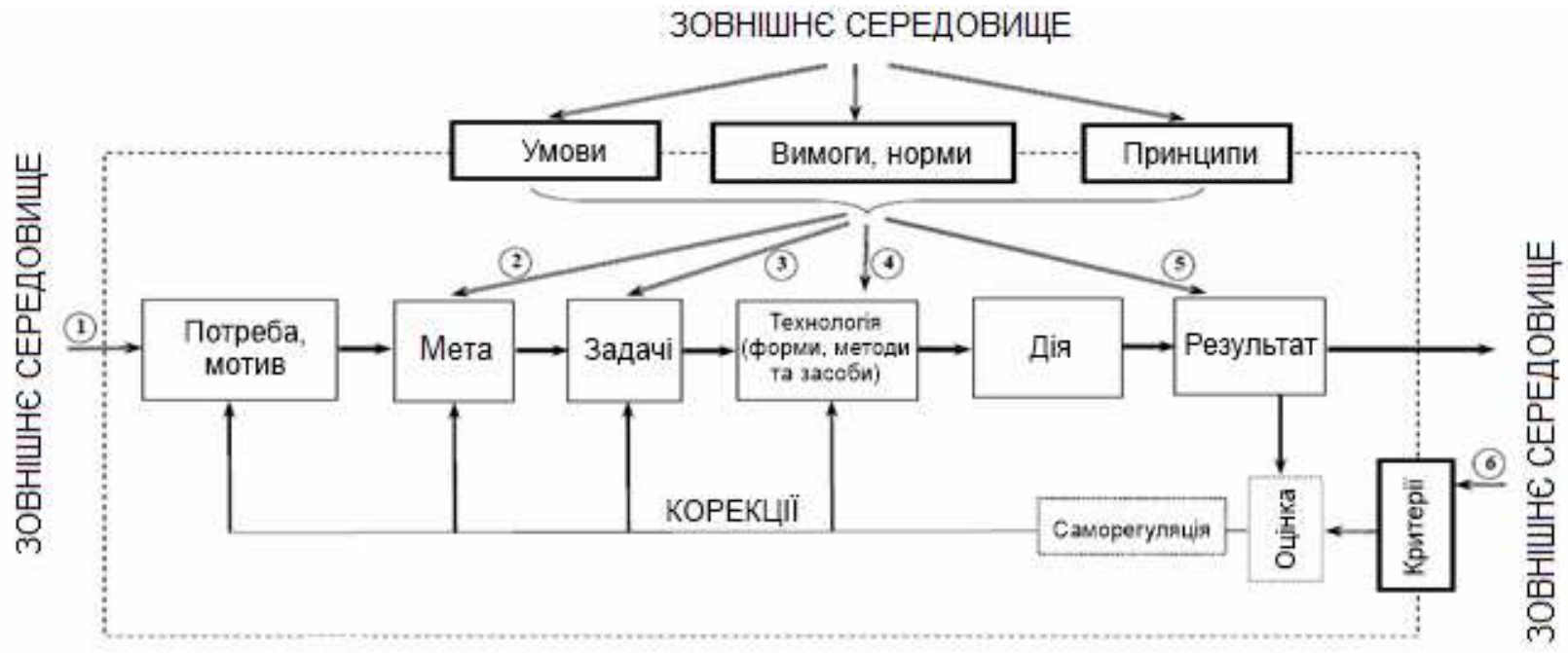

Рис. 6. Структурні компоненти в моделі діяльності Д. А. Новікова 
Горизонтальний ланцюг (жирні стрілки на рис. 6) «потреба $\rightarrow$ мотив $\rightarrow$ мета $\rightarrow$ завдання $\rightarrow$ технологія $\rightarrow$ дія $\rightarrow$ результат» відповідають одному «циклу» діяльності. Умовно границі суб'єкта, що здійснюе діяльність, позначені пунктирним прямокутником. Діяльність може бути індивідуальною або колективною, тобто суб'єкт, який здійснює діяльність, може бути окремою особистістю, а може бути i групою, колективом або організацією $[2$, с. 25 , рис. 1.1]. Дана схема декомпозиції діяльності передбачає реалізацію низки процесів - від потреби (1) до результату (5), побудована на факторі часу, тобто відноситься до часових систем, які розглядаються М. Й. Месаровичем.

На рис. 7 наведено розглянуту модель діяльності в координатах загальної моделі діяльності В. Н. Волкової.

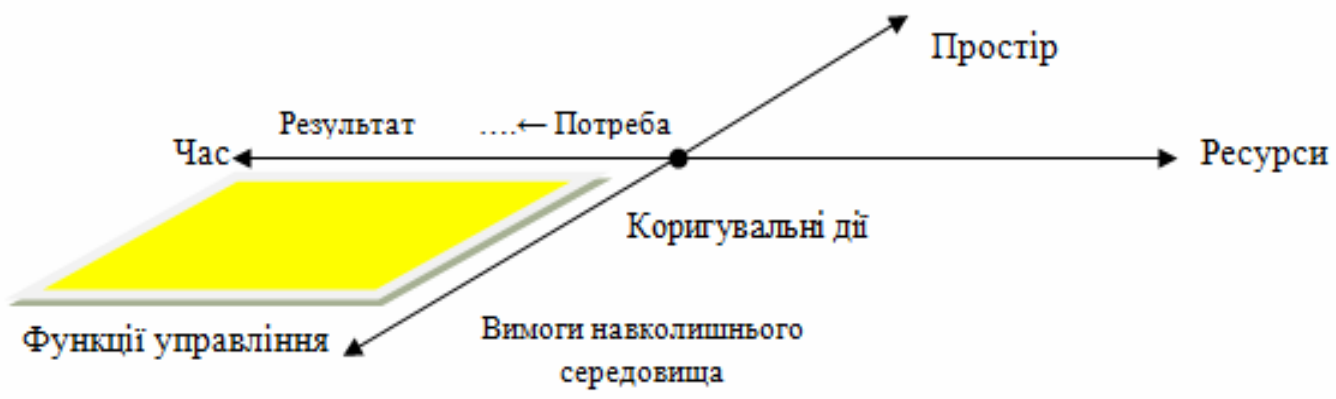

Рис. 7. Модель діяльності Д. А. Новікова в площині факторів загальної моделі діяльності В. М. Волкової

Функціонування реалізується процесами (1) - (5), а управління процесом (6), «оцінкою», «саморегуляцією» та «корекцією».

Спробуємо зіставити елементи вказаного кортежу 3 елементами декомпозиції факторів підприємства за В. М. Волковою:

- управління - управління: $\{\ldots\}$;

- ресурси - ???;

- час-???;

- простір - елементи: $\{\ldots\}$, структура: $\{\ldots\}$;

- ??? - мета дослідження: $\{\ldots\}$, дослідник: $\{\ldots\}$.

У цьому методі декомпозиції (моделювання) існування та діяльності системи важко визначити взаємний зв'язок між ознаками фактора «управління». В кортежі «базових» ознак (факторів) і властивостей відсутні фундаментальні фактори, а саме: «простір» та «ресурси».

\footnotetext{
Методологія моделювання: ВФО-елемент

Серед теоретичних робіт у галузі моделювання діяльності підприємства слід зазначити роботи C. I. Маторіна зі співавторами $[6,7]$.

У роботі [7] запропоновано новий підхід до моделювання функціонального об'єкта: «Системологічний підхід, в першу чергу, дозволяє представити бізнес-систему як функціональний об'єкт, пов'язаний вхідними і вихідними потоками з іншими об'єктами (системами). Деталізація цього положення приводить до розгляду бізнес-системи 3 трьох боків. 3 одного боку, як перехрестя вхідних і вихідних зв'язків/потоків, тобто як Вузла, з іншого - як процесу
}

(процедури) перетворення елементів, що входять вхідними потоками, в елементи, що виходять по вихідних потоках, тобто як Функції, $з$ третього - як матеріального явища, що реалізує (виконує) функцію перетворення входу у вихід, тобто як Об'єкта.

Інтеграція цих трьох аспектів дає змогу представити будь-яку бізнес- систему як елемент: Вузол - Функція - Об'єкт (ВФО-елемент, рис. 8). Формалізуються три очевидних факти:

1) будь-яка бізнес-система обов'язково міститься в структурі (є вузлом) системи вищого ярусу (надсистеми);

2) будь-яка бізнес-система обов'язково як-небудь функціонує (перетворює вхід у вихід);

3) будь-яка бізнес-система (якщо вона міститься в структурі i функціонує) обов'язково існує як матеріальне явище (персонал, будівлі, обладнання, документи тощо)».

На рис. 9 наведено модель ВФО-елемента в координатах загальної факторної моделі В. М. Волкової. В цьому методі моделювання задіяні всі можливі фактори діяльності за В. М. Волковою. 


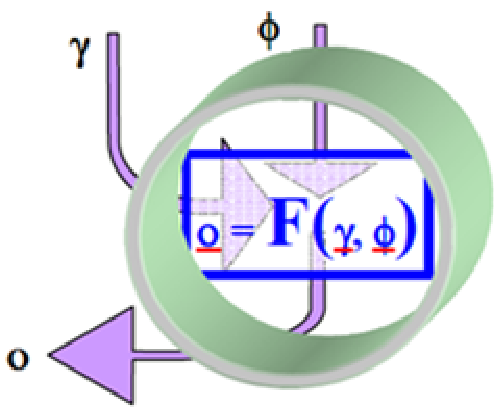

ВФО-елемент 3 вулом $(\mathrm{Y})$ - перехрестям потоків Функцією $(\mathrm{F})$ - процесом перетворення потоків $\gamma, \phi$ в потік о, об'ектом (О) - матеріальним утворенням, фізично виконуючим даний процес

Рис. 8. Модель ВФО-елемент

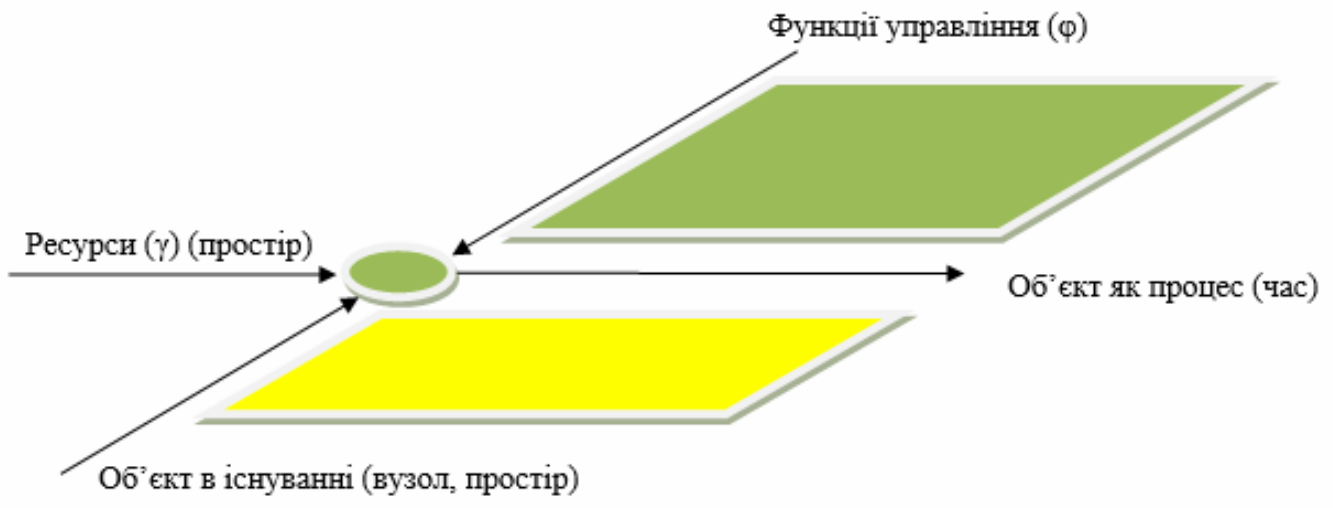

Рис. 9. Модель ВФО-елемента в площині факторів загальної моделі В. М. Волкової

У цій моделі застосовуються всі чотири фактори представлення моделі діяльності підприємства.

\section{Матрична модель підприсмства}

Д. Хлебниковим зі співавторами розглядається «матрична» модель діяльності підприємства, яка запропонована Девідом Оклі (David Auckley) [8].

Досліджуючи цю модель, Д. Хлебников визначає три основних підходи щодо формування моделей бізнес-процесів верхнього рівня, які i $\epsilon$ причиною основних розбіжностей серед менеджерів (рис. 10):

- перший підхід орієнтований на докладний опис послідовності дій, що проводяться працівниками для досягнення результату;

- другий дає змогу провести синтез бізнесу компанії і згрупувати роботи;

- третій виділяє i розглядає процеси як послідовний внесок у створення продукту, призначений для пошуку конкурентної переваги.
Такий підхід до моделювання дає змогу як результат отримувати:

- процесні (горизонтальні) організаційні структури;

- функціональні (вертикальні) організаційні структури;

- матричні (проєктні) організаційні структури [8]. 


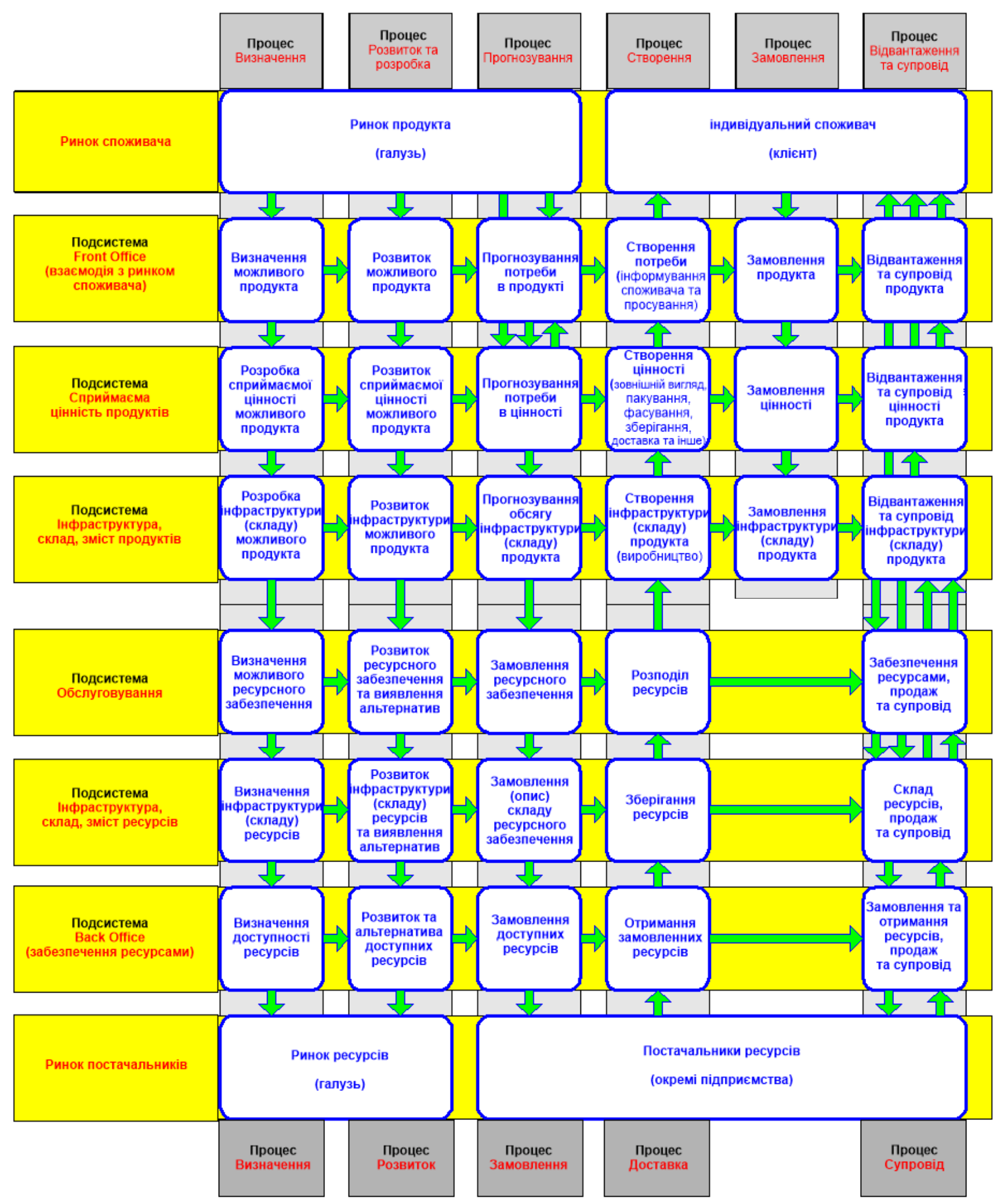

Рис. 10. Матрична модель для виробничого підприємства [8]

Гнучкість застосовуваної моделі дає змогу в матричної моделі отримати управлінські структури у результаті організаційного проєктування на базі вигляді, найбільш прийнятному для досягнення 
конкретних цілей і завдань, що стоять перед кожним конкретним напрямом діяльності. Об'єднані в єдину бізнес-систему напрямки діяльності формують, таким чином, унікальну організаційну структуру, націлену на вирішення Головної стратегічної мети підприємства [8].

3 наведеної тези випливає:

- управлінські структури мають множинний характер;

- управлінські структури $є$ унікальними для досягнення конкретних цілей і завдань.

Властивості блочних матриць забезпечують наочність зображення складних взаємозв'язків і роблять матрицю зручним інструментом логічного аналізу складних структур, де відображаються одночасно технологічний, організаційно-виробничий та економічний аспекти діяльності народногосподарських об'єктів [8].

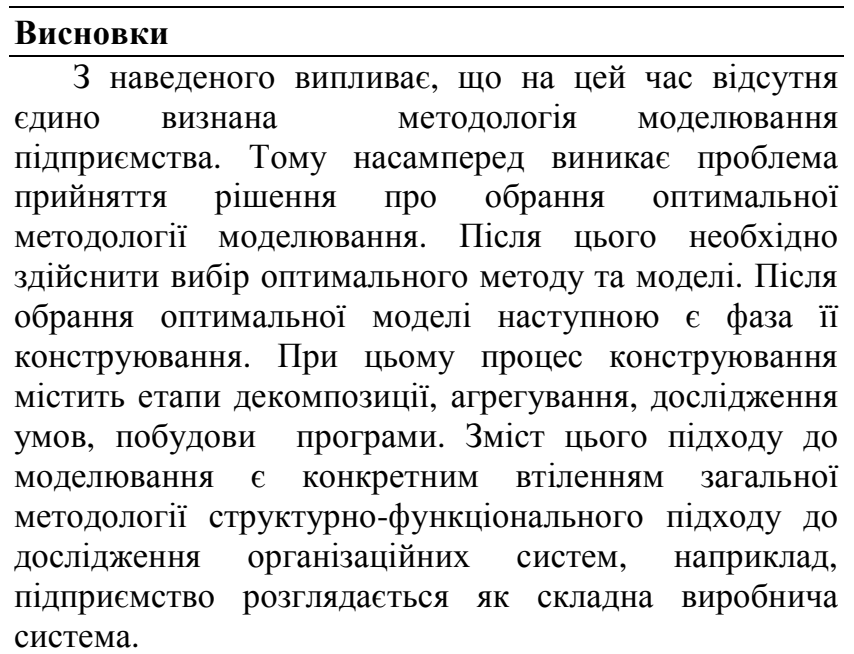

У цій методології об'єднано дві системні концепції: концепцію діяльності, яка управляється, оновлюється, організовується та стабілізується, і системотехнічну концепцію потоку, причому термін «потік» застосовується до тих ресурсів, які йдуть на відтворення функцій, а не поліструктури.

У цій моделі як фактори застосовуються ресурси та функції. На їх основі можливим $є$ формування відповідних організаційних структур. 3 цього випливає, що для організації визнається можливість формування множини організаційних структур. 3 цього стає зрозумілим зміст діяльності з інжинірингу та реінжинірингу організацій.

Наступне завдання, яке випливає 3 результатів дослідження, полягає в необхідності розроблення методу формування організаційної структури підприємства на основі функціонального підходу, який запропоновано у роботі [9].
Список використаних джерел

1. Доценко С. І., Мойсеєнко В. І., Срмоленко Л. П. Розвиток методології моделювання інформаційнокеруючих систем на залізничному транспорті. Інформаційно-керуючі системи на залізничному mранспорті. 2020. № 2 (141). С. 33-42.

2. Математические модели организаций / А. А. Воронин, М. В. Губко, С. П. Мишин, Д. А. Новиков: учеб. пособ. Москва: ЛЕНА НД, 2008. $360 \mathrm{c}$.

3. Новиков А. М., Новиков Д. А. Методология. Москва: СИН-ТЕГ, 2007. 668 с.

4. Теория систем и методы системного анализа в управлении и связи / В. Н. Волкова, В. А. Воронков, А. А. Денисов и др. Москва: Радио и связь, 1983. 248 с.

5. Клейнер Г. Б. Системная парадигма и экономическая политика. Общественные науки $u$ современность. 2007. № 2, № 3.

6. Маторин С. И., Попов А. С. «UFO-TOOLKIT»ВI-инструментарий нового поколения. Проблеми програмування. 2005. № 3. С. 53-66.

7. Маторин С. И. Анализ и моделирование бизнессистем: системологическая объектноориентированная технология / под ред. М. Ф. Бондаренко. Харьков: ХНУРЭ. 2002. 322 с.

8. Хлебников Д., Яцына А., Савушкин Л. Матричная модель предприятия. URL: http://mdhr.ru/articles/?show=print\&id=32603.

9. Доценко С. I., Савенко В. I. Теоретичне обгрунтування ізоморфізму організаційної структури підприємства. Енергетика ma комп'ютерно-інтегровані технології в АПК. Харків: ХНТУСГ, 2017. № 1 (6). С. 43-47.

Dotsenko S. I., Moiseenko V. I., Klimenko L. A., Ermolenko L. P. Justification of the choice of a methodology for the formation of models of enterprise activities.

Abstract. It has been proven that currently there is no single recognized methodology for enterprise modeling. Therefore, first of all, the problem of making a decision on the choice of the optimal modeling methodology arises. After that, it is necessary to select the optimal method and model. After choosing the optimal model, the next is the phase of its construction. At the same time, the design process "includes the stages of decomposition, aggregation, research of conditions, building a program. The content of this modeling methodology is a specific embodiment of the general methodology of the structuralfunctional approach to the study of organizational systems, for example, an enterprise is considered as a complex production system. This methodology combines two systemic concepts: the concept of activity, which is controlled, updated, organized and stabilized, and the systemic concept of flow, and the term "flow" is applied to 
those resources that go to the reproduction of functions and not the structure field. V. N. Volkova introduces the category "unit of activity (process)" in the form of a corresponding function, the implementation of which provides a specific result. But it is impossible to define the "unit of activity (process)" in this way, because each specific result will be assigned its own function! The unit for a function can be set when the same result is always obtained for it. Methodology for modeling the activities of an enterprise, proposed by D. A. Novikov and G. Kleiner are formed on the basis of the application of two factors. In the methodology proposed by G. Kleiner, there are no fundamental factors in the tuple of "basic" attributes (factors) and properties, namely, "resources" and "functions".In the methodology proposed by D.A. Novikov, there are no fundamental factors in the tuple of "basic" attributes (factors) and properties, namely, "space" and "resources." The matrix approach to modeling allows to obtain as a result: process (horizontal) organizational structures; functional (vertical) organizational structures; matrix (design) organizational structures. In this model, resources and functions are used as factors. On their basis, it is possible to form appropriate organizational structures. It follows from this that the organization recognizes the possibility of forming a plurality of organizational structures. From this, the meaning of the engineering and reengineering activities of organizations becomes clear. In the model of S. I. Matorin, all four factors are used to represent the model of the enterprise. Therefore, this methodology ensures the use of all four factors of modeling the activities of an enterprise, according to V. M. Volkova. Therefore, it can be recommended for further use.

Keywords: methodology, modeling, organized whole system, holistic approach, organization.

Надійшла 26.05.2021 p.

Доценко Сергій Ілліч, д-р техн. наук, доцент, доцент кафедри спеціалізованих комп'ютерних систем Украӥнського державного університету залізничного транспорту, Харків, Україна. E-mail: sirius_3k3@ukr.net, $\quad$ http://orcid.org/0000-0003-3021$\underline{4192 .}$.

Мойсеснко Валентин Іванович, д-р техн. наук, професор, завідувач кафедри спечіалізованих комп'ютерних систем Украӥнського державного університету залізничного транспорту, Харків, Украӥна. E-mail: mvi53@ukr.net http://orcid.org/00000003-1377-8703.

Клименко Любов Анатоліївна, канд. техн. наук, дочент, дочент кафедри спечіалізованих комп'ютерних систем Украӥнського державного університету залізничного транспорту, Харків, Україна. E-mail: klymenko.liubov73@gmail.com ORCID ID http://orcid.org/0000-0002-8252-7425
Срмоленко Людмила Павлівна, аспірант кафедри спеціалізованих комп'ютерних систем Украӥнського державного університету залізничного транспорту, Харків, Україна. E-mail: ermolenkolp1@gmail.com http://orcid.org/0000-0003-0732-3999.

Sergiy Dotsenko, Doctor of Technical Sciences, Associate Professor at the Department of specialized computer systems, Ukrainian State University of Railway Transport, Kharkiv, Ukraine. E-mail: sirius_3k3@ukr.net, http://orcid.org/0000-0003-3021-4192.

Valentin Moiseenko, Doctor of Technical Sciences, Professor, head of Department of specialized computer systems of Ukrainian State University of Railway Transport, Kharkiv, Ukraine. E-mail: mvi53@ukr.net http://orcid.org/0000-0003-1377-8703.

Lyubov Klimenko, candidate of technical sciences Associate Professor at the Department of specialized computer systems, Ukrainian State University of Railway Transport, Kharkiv, Ukraine. E-mail: klymenko.liubov73@gmail.com ORCID ID http://orcid.org/0000-0002-8252-7425

Liudmyla Yermolenko, graduate student, Department of specialized computer systems of Ukrainian State University of Railway Transport, Kharkiv, Ukraine. E-mail: $\quad$ ermolenkolp1@gmail.com http://orcid.org/0000-0003-0732-3999. 